\title{
LETTER FROM THE EDITOR-IN-CHIEF
}

JIBS plans to publish the Special Issue on Cross-Cultural Management, edited by Professor Anant Negandhi, University of Illinois at Urbana-Champaign, in Fall 1983. This Special Issue should be of major interest to scholars in international business. Professor Peter Lorange and Dr. Anders Edström are making progress as editors of a Special Issue on Strategic Planning, Autonomy, and Control Processes in Multinational Corporations, scheduled for Spring 1984.

Professor Richard M. Levich of the Graduate School of Business Administration, New York University, has resigned as Section Editor for International Finance, effective 1 July 1983 because he is taking a sabbatical leave during the 1983-1984 academic year and will be spending most of his time outside the United States. Professor Levich has performed distinguished service for JIBS in supervising the evaluation of manuscripts, in selecting reviewers, and in decision making on manuscripts in International Finance. Under his tenure as Section Editor since July 1980, JIBS has received and published more manuscripts in the International Finance field than in any other field. Further, the Journal has been publishing higher quality, including quantitative research, studies that have advanced knowledge in this field. I deeply appreciate the excellent and dedicated service of Richard Levich to JIBS.

I am very pleased that Professor Donald Lessard of the Sloan School of Management, Massachusetts Institute of Technology, will assume the responsibilities of Section Editor in International Finance on 1 July 1983. As you know, Donald Lessard is an outstanding scholar in this field and has established an excellent reputation for knowledge, research, and publications in International Finance. I am convinced that under his leadership JIBS will make further progress in publishing noteworthy articles in the field.

To stimulate the flow of manuscripts to JIBS and scholarship generally, the Section Editors have presented suggestions for research and publication of articles in their fields. In this issue we have included suggestions from Dr. Vern Terpstra on International Marketing, Dr. Holger Engberg on International Trade and Development, and Dr. Jeffrey Arpan on International Accounting. Other Section Editors will present their suggestions in subsequent issues.

William A. Dymsza

Editor-in-Chief 